\title{
Osmotic Dehydration of Pineapple Stems in Hypertonic Sucrose Solutions
}

\author{
Ronaldo dos Santos Falcão Filho', Rennan Pereira de Gusmão², Wilton Pereira da Silva², \\ Josivanda Palmeira Gomes ${ }^{2}$, Edvaldo Vasconcelos Carvalho Filho ${ }^{3}$, Anoar Abbas El-Aouar ${ }^{4}$ \\ ${ }^{1}$ Federal Institute of Rio Grande do Norte, Currais Novos, Brazil \\ ${ }^{2}$ Federal University of Campina Grande, Campina Grande, Brazil \\ ${ }^{3}$ Federal University of Rio Grande do Norte, Santa Cruz, Brazil \\ ${ }^{4}$ Federal University of Paraíba, João Pessoa, Brazil \\ Email: ronaldo.falcao@ifrn.edu.br, rennangusmao@gmail.com, wiltonps@uol.com.br, josivanda@gmail.com, \\ edvaldovasconcelos@yahoo.com.br, anoarabbas@gmail.com
}

Received 1 July 2015; accepted 8 September 2015; published 11 September 2015

Copyright (C) 2015 by authors and Scientific Research Publishing Inc.

This work is licensed under the Creative Commons Attribution International License (CC BY).

http://creativecommons.org/licenses/by/4.0/

(c) (i) Open Access

\begin{abstract}
The present study provides the evaluation in the influence of the variables: temperature (T), concentration of the osmotic solution (C) and ratio of fruit and osmotic solution (F:OS) during the osmotic dehydration of slices of pineapple stem variety Perola, on the responses: water loss (WL), mass loss (ML), gain of solids (GS) and ratio of gain of solids and water loss (GS/WL). The centesimal composition was determined both in the raw material and in the dehydrated product. To optmize the process, the studied factors were: temperature (T), with factorial points $\mathbf{- 1}$ equal to $30^{\circ} \mathrm{C}$ and +1 equal to $50^{\circ} \mathrm{C}$; concentration of sucrose solution (C), with factorial points -1 equal to $40 \mathrm{~g} \cdot 100 \mathrm{~g}^{-1}$ and +1 equal to $60 \mathrm{~g} \cdot 100 \mathrm{~g}^{-1}$ and ratio of fruit and osmotic dehydration solution (F:OS), with factorial points -1 and +1 equal to $1: 20$ and 3:20, respectively. In all essays, the dehydration time was 4 hours. The essays showed that F:OS was not significant in any responses; the models adopted were predictive and fitted for WL and ML, and reasonable for GS and GS/WL. The temperature was the most significant variable in the process; the optimized values were: $\mathrm{T}=50^{\circ} \mathrm{C}, \mathrm{C}=40 \mathrm{~g}$ $100 \mathrm{~g}^{-1} \mathrm{e} \mathrm{F}: \mathrm{OS}=3: 20$. The product needs a complementary drying to adapt itself to the legislation demands.
\end{abstract}

\section{Keywords}

Pineapple, Dried Fruit, Experimental Design

\section{Introduction}

Brazil is the largest tropical fruit producer in the world, and due to its diversified conditions of soil and climate,

How to cite this paper: Falcão Filho, R.S., Gusmão, R.P., Silva, W.P., Gomes, J.P., Carvalho Filho, E.V. and El-Aouar, A.A. (2015) Osmotic Dehydration of Pineapple Stems in Hypertonic Sucrose Solutions. Agricultural Sciences, 6, 916-924. 
it can also cultivate fruits typical of temperate and subtropical climates, which have a high potential in the international market [1].

In 2008, Brazil was the largest pineapple producer in the world, with a total produce of 2.5 million tons, corresponding to approximately 482 million dollars, overcoming countries in fast development, such as China and India, $5^{\text {th }}$ and $6^{\text {th }}$ largest producers, respectively [2].

In 2009, Brazil's Northeast Region was the second ranked among the country regions in fruit production, the Southeast being the first, but when it comes to pineapple the Northeast leads with $46 \%$ of national producing and Paraíba, the state with the largest produce, accounting for about $20 \%$ of the Brazilian production [3].

The pineapple has long been the favorite non-citrus fruit in the tropical and subtropical countries, especially because of the attractiveness of its flavor and aroma, and it contains a wide variety of vitamins and mineral nutrients, particularly vitamins A and C, and potassium [4].

Pineapple (Ananas comosus L., Merrill) belongs to the monocotyledon family bromeliaceae and is the third most abundant tropical fruit cultivated in Brazil. The Pérola variety has high sugar content (14 - 16 Brix), and low acidity and it is mainly consumed in natura or used for juice production (single strength or concentrate) [5].

It has been shown that $30 \%$ of the foods are wasted, like: peels, stems, leaves and seeds. That happens due to a lack of information about the dietary value of these products and their correct processing techniques [6]. Thus, it is important to make rational use of all the fractions of the foods.

It is an established fact that a large portion of the food production in Brazil is wasted, especially fruits. Therefore, the process of osmotic dehydration is a good technique for pineapple conservation through moisture reduction. This technique is widely used for a pre-drying followed by a conventional convective drying, or solar drying, so that moisture content below $25 \mathrm{~g} \cdot 100 \mathrm{~g}^{-1}$ is reached. Using this technology, the pineapples can be preserved longer than the in natura fruit, making it possible to sell them in non-producing regions, aggregating value for the producer and avoiding part of that unwanted wasting.

Solar-osmotic dehydration has attracted interest, particularly in countries with a wide diversity of fruits, ample availability of sugar and high incidence of solar rays throughout the year [7].

Using the response-surface methodology (RSM) as an optimization technique, as described by [8], it is possible to obtain the best relation and learn which of the variables in the process have a significant influence upon osmotic dehydration, as showed in the studies of [9] [10].

The aim of this work was to assess the influence of the variables: temperature, concentration of the sucrose solution and ratio of fruit and solution during osmotic dehydration of slices of pineapple stem from the variety "Pérola” [Ananas comosus (L.) Merrill cv. "Pérola"], as well as the following responses: water loss, mass loss, gain of solid material and the optimization parameter (ratio of gain of solids and water loss) and chemical composition of the raw material and the dehydrated product.

\section{Materials and Methods}

The study was carried out at the Fruit and Vegetable Processing Laboratory of the IFRN at city of Currais Novos. The pineapples of the variety Pérola, cultivated around the municipality of Santa Rita, Paraíba, Brazil, were purchased at the market in the city of Currais Novos, Rio Grande do Norte, Brazil.

The selection of pineapples was done according to color intensity (green, slightly yellowish), content of soluble solid material (12 - $16 \mathrm{~g} \cdot 100 \mathrm{~g}^{-1}$ ), same size and shape, in order to obtain homogeneous samples [4].

\subsection{Chemical Characterization}

The raw material and the product obtained through osmotic dehydration were analyzed as to the relative contents of moisture, ashes, crude fiber, proteins, lipids and total sugars, as stipulated by Brazil [11].

\subsection{Factorial Design for Optimizing Osmotic Dehydration}

After preliminary tests it was verified that the studied variables (temperature, concentration of sucrose solution and ratio of fruit and osmotic dehydration solution) had a linear behavior, then, the factorial design $2^{3}$ with four repetitions at the central point was utilized [8]. The studied factors were: temperature (T), with factorial points -1 equal to $30^{\circ} \mathrm{C}$ and +1 equal to $50^{\circ} \mathrm{C}$; concentration of sucrose solution $(C)$, with factorial points -1 equal to $40 \mathrm{~g} \cdot 100 \mathrm{~g} \mathrm{~g}^{-1}$ and +1 equal to $60 \mathrm{~g} \cdot 100 \mathrm{~g}^{-1}$ and ratio of fruit and osmotic dehydration solution (F:OS) with fac- 
torial points -1 and +1 equal to $1: 20$ and 3:20, respectively.

Twelve essays were carried out in triplicate, eight factorial trials and four repetitions at the central point; the design is reported in Table 1.

Table 2 shows the sequence of the 12 essays of factorial design for optimizing osmotic dehydration of slices of pineapple stem from the variety "Pérola".

\subsection{Procedure of Osmotic Dehydration}

After removing the crowns, the fruits were washed in flowing water and immersed in a solution of commercial neutral detergent at $1 \%$ for 15 minutes, for a first cleaning, and then, submerged in chlorinated water (8 to 10 ppm of active chlorine) for 10 minutes, to disinfection. That procedure was followed by rinsing with distilled water [12].

The pineapples were cut to isolate the stems, and these were sliced in the shape of infinite plane plates, with approximately $50 \mathrm{~mm}$ length and $5 \mathrm{~mm}$ thick.

The dehydration solutions were produced by diluting commercial sucrose in distilled water, using a mechanical agitator MARCONI ${ }^{\circledR}$; solutions were calculated according to the concentrations in the design, and controlled with a handheld refractometer, model R-5000 ATAGO $^{\circledR}$.

The samples of pineapple stem slices underwent osmotic dehydration in closed glass pots containing dehydration solution and fruit in the ratios, concentrations and temperatures described in the experimental design. Osmotic dehydration was conducted without agitation in a drying oven for dehydration for four hours.

After dehydration time, the samples were rinsed with distilled water for about 5 seconds in order to remove the excess of solute retained on the product surface, and then they were drained with a paper towel to remove the excess of surface water [12].

Right after the osmotic dehydration, the samples were analyzed for moisture content, according to [11].

Table 1. Real and coded levels of independent variables in the factorial design.

\begin{tabular}{|c|c|c|c|}
\hline \multirow{2}{*}{ Independent variables } & \multicolumn{3}{|c|}{ Levels } \\
\hline & -1 & 0 & +1 \\
\hline$T\left({ }^{\circ} \mathrm{C}\right)$ & 30 & 40 & 50 \\
\hline$C\left(\mathrm{~g} \cdot 100 \mathrm{~g}^{-1}\right)$ & 40 & 50 & 60 \\
\hline $\mathrm{F}: \mathrm{OS}$ & $1: 20$ & $1: 10$ & $3: 20$ \\
\hline
\end{tabular}

Table 2. Factorial design $2^{3}$ with 4 repetitions at the central point with coded and decoded factors.

\begin{tabular}{cccc}
\hline Essay & $T\left({ }^{\circ} \mathrm{C}\right)$ & $C\left(\mathrm{~g} \cdot 100 \mathrm{~g}^{-1}\right)$ & $\mathrm{F}: \mathrm{OS}$ \\
1 & $30(-1)$ & $40(-1)$ & $1: 20(-1)$ \\
2 & $30(-1)$ & $40(-1)$ & $3: 20(+1)$ \\
3 & $30(-1)$ & $60(+1)$ & $3: 20(+1)$ \\
4 & $30(-1)$ & $60(+1)$ & $1: 20(-1)$ \\
5 & $50(+1)$ & $40(-1)$ & $3: 20(-1)$ \\
6 & $50(+1)$ & $40(-1)$ & $3: 20(+1)$ \\
7 & $50(+1)$ & $60(+1)$ & $1: 20(-1)$ \\
8 & $50(+1)$ & $60(+1)$ & $1: 10(0)$ \\
9 & $40(0)$ & $50(0)$ & $1: 10(0)$ \\
11 & $40(0)$ & $50(0)$ & $1: 10(0)$ \\
12 & $40(0)$ & $50(0)$ & $1: 10(0)$ \\
\hline
\end{tabular}




\subsection{Mathematical-Statistical Treatment of Data}

The calculations of water loss (WL), mass loss (ML), solids gain (SG) and ratio of solids gain and water loss (SG/WL) in the process of osmotic dehydration was done by using the Equations (1), (2) and (3) prescribed by [10].

$$
\begin{gathered}
\operatorname{ML}(\%)=\frac{\left(w_{i}-w_{f}\right) \cdot 100}{w_{i}} \\
\operatorname{WL}(\%)=\frac{\left(w_{i} X_{i}-w_{f} X_{f}\right) \cdot 100}{w_{i}} \\
\operatorname{SG}(\%)=\frac{\left[w_{f} \cdot\left(1-\frac{X_{f}}{100}\right)-w_{i} \cdot\left(1-\frac{X_{i}}{100}\right)\right] \cdot 100}{w_{i}}
\end{gathered}
$$

The linear models described by Equation (4) were filted to the experimental data by means of linear regression, using the software Statistica $7.0^{\circledR}$.

$$
\begin{aligned}
y= & \beta_{0}+\beta_{1} \cdot x_{1}+\beta_{2} \cdot x_{2}+\beta_{1} \cdot x_{1}+\beta_{3} \cdot x_{3}+\beta_{1,2} \cdot x_{1} \cdot x_{2}+\beta_{1,3} \cdot x_{1} \cdot x_{3} \\
& +\beta_{1,2} \cdot x_{1} \cdot x_{2}+\beta_{2,3} \cdot x_{2} \cdot x_{3}+\beta_{1,2,3} \cdot x_{1} \cdot x_{2} \cdot x_{3}+\varepsilon
\end{aligned}
$$

The models were tested for the prediction of regression and the lack of fit from the variance analysis (ANOVA) through the Fischer test $(F)$, and the determination coefficients $\left(R^{2}\right)$ were calculated to check the significance of the linear models used in the factorial design.

The effects and interactions with $p \geq 0.05$ were discarded from the models, since they are statistically insignificant. The models considered predictive were those with an $F_{\text {calc }} / F_{\text {tab }}$ ratio of at least 4 for the regression, and only those with $R^{2} \geq 0.7$ were considered significant. Lack of fit was also used as a criterion to assess the prediction capability of the statistic model, when it showed a value of $F_{\text {calc }}$ less than the value of $F_{\text {tab }}$ for a significance level of $p \geq 0.05$ [8].

\section{Results and Discussion}

Table 3 shows the experimental data of WL, ML, GS and GS/WL regarding the independent variables of the process. The table reports that highest temperatures, as well as largest concentrations of dehydration solutions and highest ratios of fruit and dehydration solution led to the largest contents of water loss (WL)-which reached 2.63 times higher than the minimal loss condition-whereas the mass loss (ML) was 2.92 times higher than the minimal loss condition. But these conditions had the largest gain of solids (GS), which is not interesting, since in this case, the gain of solids contents represents just a gain of sugar, and that is not necessary because the in natura pineapples already contains a high concentration of sugars. Therefore, the optimization of the dehydration process is best attained through the variable GS/WL. According to [9], the optimization is reached in the region where you have the highest WL and lowest GS, so that the ratio GS/WL is minimal.

The water transfer is one of the most important aspects of osmotic dehydration. The main mechanism of mass transfer is diffusion, due to the concentration gradient between the osmotic solution and the food [13]. Figure 1 (A) shows that the significant effects for $\mathrm{WL}$, at $5 \%$ of significance level, were temperature and concentration of dehydration solution: both effects have a strong influence on water loss, because they are positive and proximal. [9] [14], studying osmotic dehydration of tomatoes and mangoes (of the variety Tommy), respectively, also found out that the process temperature and the concentration of the dehydrating solution were among the significant and positive factors in water loss. However, [15] treated pineapples with osmotic solutions in various concentrations and obtained a constant reduction of the water content, regardless of the osmotic treatment used. [12] evaluated water loss in pineapple slices through osmotic dehydration and observed that several factors had an influence, besides temperature and concentration of solution, with a significant effect, measured by test $\mathrm{F}$ ( $\mathrm{P}<$ 0.01 ), for the following interactions: time $\times$ cultivar, temperature $\times$ cultivar, temperature $\times$ degree of agitation and cultivar $\times$ degree of agitation. 
Table 3. Experimental values obtained in the essays of factorial design.

\begin{tabular}{cccccccc}
\hline & \multicolumn{3}{c}{ Independent variables } \\
\cline { 2 - 8 } & $T\left({ }^{\circ} \mathrm{C}\right)$ & $C\left(\mathrm{~g} \cdot 100 \mathrm{~g}^{-1}\right)$ & $\mathrm{F}: \mathrm{OS}$ & $\mathrm{WL}\left(\mathrm{g} \cdot 100 \mathrm{~g}^{-1}\right)$ & $\mathrm{ML}\left(\mathrm{g} \cdot 100 \mathrm{~g}^{-1}\right)$ & $\mathrm{GS}\left(\mathrm{g} \cdot 100 \mathrm{~g}^{-1}\right)$ & $\mathrm{GS} / \mathrm{WL}$ \\
\hline 1 & $30(-1)$ & $40(-1)$ & $1: 20(-1)$ & 16.94 & 10.62 & 6.32 & 0.37 \\
2 & $30(-1)$ & $40(-1)$ & $3: 20(+1)$ & 14.50 & 9.03 & 5.47 & 0.38 \\
3 & $30(-1)$ & $60(+1)$ & $3: 20(+1)$ & 23.69 & 14.88 & 8.81 & 0.37 \\
4 & $30(-1)$ & $60(+1)$ & $1: 20(-1)$ & 23.54 & 13.54 & 10.00 & 0.43 \\
5 & $50(+1)$ & $40(-1)$ & $1: 20(-1)$ & 25.72 & 18.75 & 6.97 & 0.27 \\
6 & $50(+1)$ & $40(-1)$ & $3: 20(+1)$ & 24.51 & 18.06 & 6.45 & 0.26 \\
7 & $50(+1)$ & $60(+1)$ & $3: 20(+1)$ & 37.02 & 26.40 & 10.62 & 0.29 \\
8 & $50(+1)$ & $60(+1)$ & $1: 20(-1)$ & 36.38 & 25.43 & 10.95 & 0.30 \\
9 & $40(0)$ & $50(0)$ & $1: 10(0)$ & 25.44 & 16.20 & 9.24 & 0.36 \\
10 & $40(0)$ & $50(0)$ & $1: 10(0)$ & 27.55 & 17.50 & 10.05 & 0.36 \\
11 & $40(0)$ & $50(0)$ & $1: 10(0)$ & 29.21 & 19.74 & 9.47 & 0.32 \\
12 & $40(0)$ & $50(0)$ & $1: 10(0)$ & 26.54 & 17.24 & 9.31 & 0.35 \\
\hline
\end{tabular}

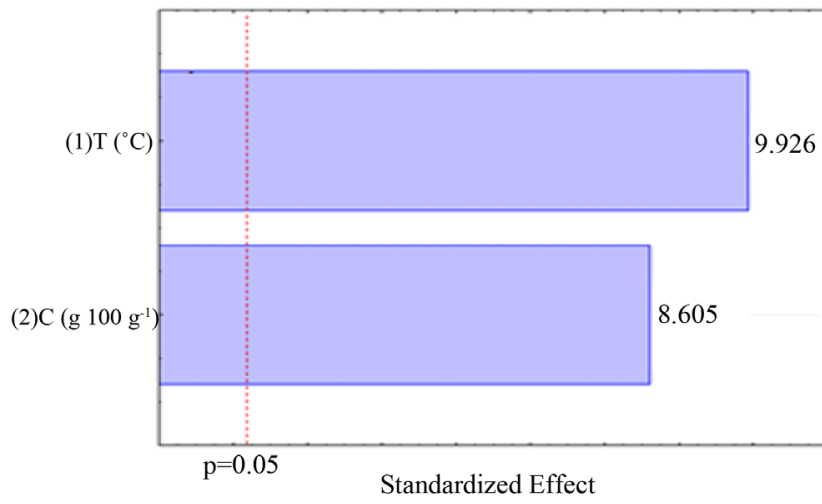

(a)

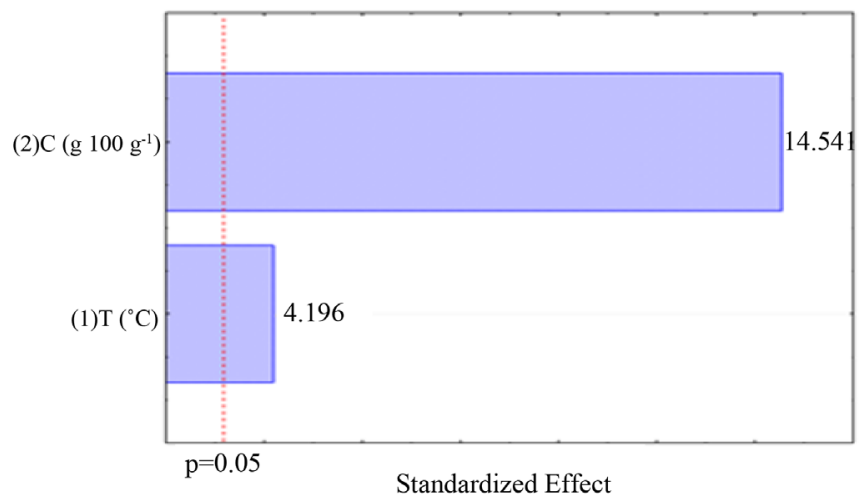

(c)

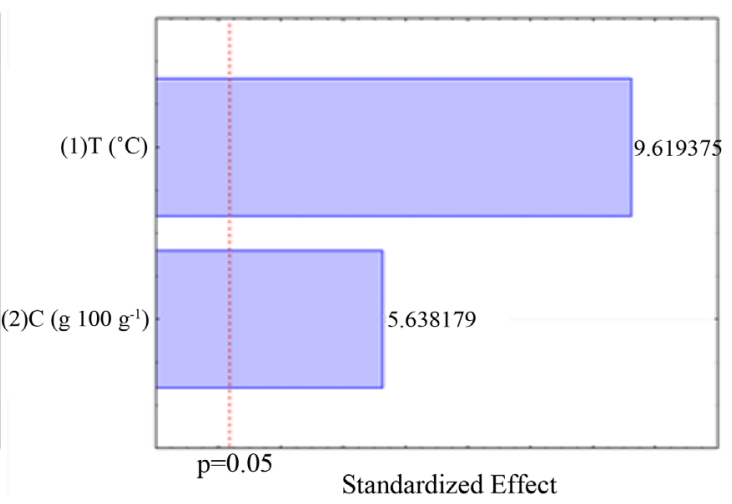

(b)

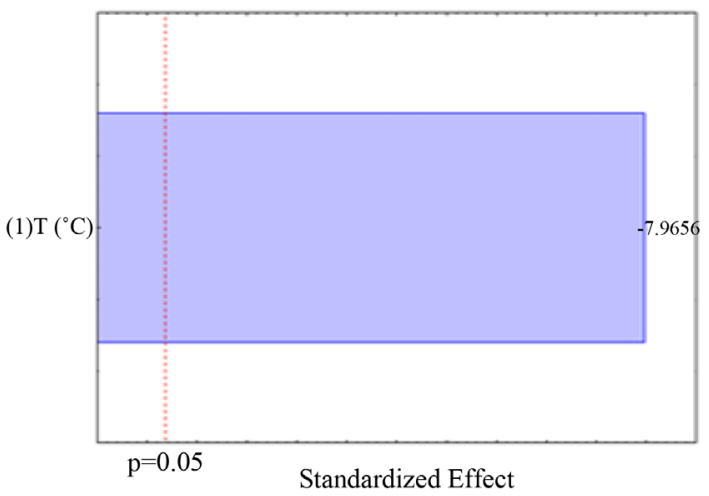

(d)

Figure 1. Pareto diagrams showing the significant effects for (a) loss of water (WL); (b) loss of mass; (c) gain of solids and (d) ratio gain of solids and loss of water.

In Figure 1(b) it can be observed that ML followed a pattern similar to that of WL, as noted by [11] in their 
experiments, but the concentration was an effect with less relevance than temperature. That is due to the solids incorporated into the product during dehydration, as predicted by [16]. But [17] found out in their experiments of osmotic dehydration of peaches that the values of mass loss were less than those of water loss.

Figure 1(c) clearly shows that the effect having the most influence on GS was concentration, as ML is function of WL and GS, concentration must be less significant to ML, because of the incorporation of solids, even though a higher concentration of dehydrating solution generates a higher potential of mass transfer, which would favor ML.

Figure 1(d) shows that the only significant effect for the optimization variable GS/WL ratio was temperature, which had a negative effect on the parameter. That is normal, since the ratio GS/WL tends to zero when the process tends to its optimum and the goal is to achieve a minimum of solids incorporation and a maximum of water loss in the product during the osmotic process, as shown by [10].

Lastly, it can be perceived that the variable ratio of fruit and dehydration solution (F:OS) was not significant $(p<0.05)$ for any of the studied responses. With that is possible to affirm that can use the highest ratio of fruit in relation to the dehydrating solution, which in this case was 3 parts of fruit to 20 of solution (3:20). Such authors as [18] [19] used in their studies of dehydration the fixed ratio of 1:10 in order to maintain the osmotic potential during the processes, but the content of solute used in osmotic dehydration has a great influence on the costs of the final product, but the 3:20 ratio proved effective, thus it can be used, in the conditions of this study, and generate an acceptable product.

Equations (5)-(8) in Table 4 represent the linear models fitted to the experimental points of factorial design. Equations (5) and (7) represent WL and ML; the two models proved predictive, because the $F_{\mathrm{c}} / F_{\text {tab }}$ ratios were greater than 4 in both cases. They are also well fitted, with $R^{2}=0.94$ and the part representing the lack of fit of non-significant models by the Fischer test with $F_{\text {tab }}$ values greater than $F_{c}$. Therefore, it is possible to affirm that the fitted linear models reliably represent the WL and ML phenomena in the stem of pineapples treated osmotically, in the studied range. Temperature and concentration increments positively influenced WL and ML. These results were expected, according to [20], who studied osmotic dehydration in apples and realized that WL and ML were strongly influenced when the temperature was raised from $25^{\circ} \mathrm{C}$ to $55^{\circ} \mathrm{C}$. [21] showed that an increase in the concentration of the sucrose osmotic solution also raised WL in pineapples, due to an increase in the gradient of osmotic pressure in the solution.

Equation (6) represents the model fitted to GS experimental points, which proved to be predictive, with $F_{\mathrm{c}}$ over 5 times higher than $T_{\text {tab. }}$; analysis of the model also showed a reasonable $R_{2}$ and a slight mismatch.

Thus, the GS model was taken into account in the determination of the optimization variable GS/WL shown in Table 5 by Equation (8).

As it has been shown, the F:OS ratio is not a variable that influences any of the responses studied, and concentration does not influence the GS/WL optimization in the conditions studied and statistical model chosen (the

Table 4. Analysis of linear models fitted experimental points obtained in factorial design.

\begin{tabular}{cccccccccc}
\hline & \multicolumn{3}{c}{ Regression } & \multicolumn{3}{c}{ Mismatch } \\
\hline & \multicolumn{2}{c}{ Equation } & $R^{2}$ & $F_{\mathrm{c}}$ & ${ }^{*} F_{\text {tab }}$ & $F_{\mathrm{c}} F_{\text {tab }}$ & $F_{\mathrm{c}}$ & ${ }^{*} F_{\text {tab }}$ & $F_{\mathrm{c}} / F_{\text {tab }}$ \\
\hline $\mathrm{WL}$ & $\mathrm{WL}=25.92+5.62 T+4.87 C(5)$ & 0.94 & 71.04 & 4.26 & 16.68 & 1.32 & 6.94 & 0.19 \\
$\mathrm{GS}$ & $\mathrm{GS}=8.64+0.57 T+1.90 C(6)$ & 0.83 & 23.10 & 4.26 & 5.42 & 7.39 & 6.94 & 1.06 \\
$\mathrm{ML}$ & $\mathrm{ML}=17.28+5.07 T+2.97 C(7)$ & 0.94 & 81.12 & 4.26 & 19.04 & 0.65 & 6.94 & 0.09 \\
$\mathrm{GS} / \mathrm{WL}$ & $\mathrm{GS} / \mathrm{WL}=0.34-0.05 T(8)$ & 0.83 & 49.12 & 4.96 & 9.90 & 1.46 & 8.89 & 0.16 \\
\hline
\end{tabular}

Table 5. Optimized value for osmotic dehydration.

\begin{tabular}{ccc}
\hline Process variable & Coded value & +1 \\
$T\left({ }^{\circ} \mathrm{C}\right)$ & -1 & 50 \\
$C\left(\mathrm{~g} \cdot 100 \mathrm{~g}^{-1}\right)$ & $+1 \quad 30$ \\
$\mathrm{~F}: \mathrm{OS}$ & $3: 20$ \\
\hline
\end{tabular}


linear model). The optimization conditions for osmotic dehydration of sliced pineapple stems are understood to be those displayed in Table 5 .

From the values of temperature, concentration and ratio of fruit and solution shown in Table 5 and using fitted values, the loss of water was estimated at $26.37 \mathrm{~g} \cdot 100 \mathrm{~g}^{-1}$, loss of mass at $19.38 \mathrm{~g} \cdot 100 \mathrm{~g}^{-1}$, gain of solids at $7.31 \mathrm{~g} \cdot 100 \mathrm{~g} \mathrm{~g}^{-1}$ and ratio of gain of solids and loss of water at 0.29 . These values approach the average experimental values for the same conditions shown in Table 4. The relative errors were $7.00 \%$ for WL, $6.81 \%$ for ML, $11.76 \%$ for GS and $10.34 \%$ for GS/WL; the error values reflect the quality of the model fits.

Table 6 presents the results of the centesimal composition of the pineapple and the product after osmotic dehydration, utilizing the process conditions set in the optimization. In relation with the raw material, the moisture $\left(84.20 \mathrm{~g} \cdot 100 \mathrm{~g}^{-1}\right)$ and sugar contents $\left(14.50 \mathrm{~g} \cdot 100 \mathrm{~g}^{-1}\right)$ are in agreement with those found by [4] and those found at [22], which were $86.07 \%$ e $86.30 \%$ for the sugars and $13.86 \%$ e $12.3 \%$ for moisture, respectively. The values found for the others components showed great disparities like, for example, the values found for proteins by [4] was $0.59 \%$, while [22] found it to be $0.9 \%$. That variation in results can be explained by some factors, such as climate conditions and the composition of soil, which have a direct bearing on the composition of plants, as shown by [23]. Alternatively, according to [24], these possible discrepancies can be due to the structure of the fruit tissue, resulting in different behaviors during processing.

About the product after osmotic dehydration, a variation of components was perceived in comparison to the raw material. As expected, the moisture levels decreased $\left(76.31 \mathrm{~g} \cdot 100 \mathrm{~g}^{-1}\right)$, since the objective of the process is to dehydrate the material. An important increase in the content of total sugars $\left(19.31 \mathrm{~g} \cdot 100 \mathrm{~g}^{-1}\right)$ can also be observed in Table 6. This phenomenon is predictable and to be expected, according to [25], because in an osmotic dehydration process occur three basic mass flows, namely: the water exit of the material into the hypertonic solution, solutes are incorporated from the solution into the material and to a lesser extent-solutes leave the product into the dehydration solution [16] [26] [27].

Since all the contents of components were calculated in wet basis, the increase in concentration was due to the loss of moisture in the product.

\section{Conclusions}

Statistical modeling of factorial design has shown that the variable F:OS was not significant to any of the responses studied, proving that in the process of osmotic dehydration, the costs with solutes can be lowered.

The models fitted for WL and ML were very predictive and fitted, with errors lower than $10 \%$, relative to the experimental points. At the same time, the models for GS and GS/WL were predictive and reasonably fitted, showing relative errors slightly above $10 \%$.

Temperature was the independent variable studied which had a significant impact on the optimization of the process, leading to these values: $T=50^{\circ} \mathrm{C}, C=40 \mathrm{~g} \cdot 100 \mathrm{~g}^{-1}$ e F:OS $=3: 20$.

Chemical composition of the raw material showed values of moisture and sugars in agreement with the literature, but disparities in relation with the contents of the others components studied.

The product obtained through dehydration had moisture levels lower than the raw material, as was expected; the remaining components underwent a rise in concentration.

Table 6. Centesimal composition of raw material and of the post-osmotic dehydration product.

\begin{tabular}{ccc}
\hline & \multicolumn{2}{c}{ Contents $\left(\mathrm{g} \cdot 100 \mathrm{~g}^{-1}\right)$} \\
\hline Component & Raw material & Post-dehydration product. \\
\hline Moisture & 84.20 & 76.31 \\
Ashes & 0.53 & 1.02 \\
Lipids & 0.82 & 1.00 \\
Proteins & 0.45 & 0.32 \\
Crude fiber & 1.15 & 2.94 \\
Total sugars & 14.50 & 19.31 \\
\hline
\end{tabular}


The product must go through complementary drying in order to reach the maximum moisture content allowed by legislation.

\section{References}

[1] Alves, R.E., Brito, E.A., Rufino, M.S.M. and Sampaio, C.G. (2008) Antioxidant Activity Measurement in Tropical Fruits: A Case Study with Acerola. Acta Horticulturae, 773, 299-305.

http://dx.doi.org/10.17660/ActaHortic.2008.773.45

[2] FAO (2011) Food and Agricultural Commodities Production. http://faostat.fao.org/site/339/default.aspx

[3] Sidra (2009) IBGE System Auto Recovery. http://www.sidra.ibge.br

[4] Valente, P.P.S.S. (2007) Desidratação osmótica e secagem de abacaxi (Ananas comosus L., Merril), variedade pérola. PhD Thesis, Universidade Estadual de Campinas, Campinas,107 p.

[5] Carvalho, L.M.J., Castro, I.M. and Silva, C.A.B. (2008) A Study of Retention of Sugars in the Process of Clarification of Pineapple Juice (Ananas comosus, L. Merril) y Micro and Ultrafiltration. Journal of Food Engineering, 87, 447-454. http://dx.doi.org/10.1016/j.jfoodeng.2007.12.015

[6] Karim, M.A. and Hawlader, M.N.A. (2005) Mathematical Modelling and Experimental Investigation of Tropical Fruits Drying. International Journal of Heat and Mass Transfer, 48, 4914-4925. http://dx.doi.org/10.1016/j.ijheatmasstransfer.2005.04.035

[7] Togrul, I.T. and Dursul, P. (2004) Modelling of Thin Layer Drying Kinetics of Some Fruits under Open-Air Sun Drying Process. Journal of Food Engineering, 65, 413-425. http://dx.doi.org/10.1016/j.jfoodeng.2004.02.001

[8] Myers, R.H. and Montgomery, D.C. (2002) Response Surface Methodology: Process and Product Optimization Using Designed Experiments. 2nd Edition, Wiley, New York.

[9] Almeida, F.A.C., Ribeiro, C.F., Tobinaga, S. and Gomes, J.P. (2005) Otimização do processo de secagem osmótica na obtenção de produtos secos da manga Tommy Atkins. Revista Brasileira de Engenharia Agrícola e Ambiental, 9, 576-584. http://dx.doi.org/10.1590/S1415-43662005000400022

[10] El-Aouar, A.A., Azoubel, PM., Barbosa Jr., J.L. and Murr, F.E.X. (2006) Influence of the Osmotic Agent on the Osmotic Dehydration of Papaya (Carica papaya L.). Journal of Food Engineering, 75, 267-274.

http://dx.doi.org/10.1016/j.jfoodeng.2005.04.016

[11] BRASIL (2008) Ministério da Saúde. Agência de Vigilância Sanitária (ANVISA). Instituto Adolfo Lutz. Métodos Físico-Químicos para Análise de Alimentos. Brasília.

[12] Dionello, R.G., Berbert, P.A., Molina, M.A.B., Pereira, R.C., Viana, A.P. and Carlesso, V.O. (2009) Desidratação osmótica de frutos de duas cultivares de abacaxi em xarope de açúcar invertido. Revista Brasileira de Engenharia Agrícola e Ambiental, 13, 596-605.

[13] Atarés, L., Chiralt, A. and González-Martínez, C. (2008) Effect of Solute on Osmotic Dehydration and Rehydration of Vacuum Impregnated Apple Cylinders (cv. Granny Smith). Journal of Food Engineering, 89, 49-56. http://dx.doi:10.1016/j.jfoodeng.2008.04.002

[14] Tonon, R.V., Baroni, A.F. and Hubinger, M.D. (2004) Osmotic Dehydration of Tomato in Ternary Solutions: Influence of Process Variables on Mass Transfer Kinetics and an Evaluation of the Retention of Carotenoids. Journal of Food Engineering, 65, 413-425. http://dx.doi:10.1016/j.jfoodeng.2007.03.008

[15] Lombard, G.E., Oliveira, J.C., Fito, P. and Andrés, A. (2008) Osmotic Dehydration of Pineapple as a Pre-Treatment for Further Drying. Journal of Food Engineering, 85, 277-284. http://dx.doi:10.1016/j.jfoodeng.2007.07.009

[16] Raoult-Wack, A.L., Lenart, A. and Guilbert, S. (1994) Recent Advances in the Osmotic Dehydration of Foods. Trends in Food Science \& Technology, 5, 225-260.

[17] Conceição Silva, M.A., Silva, Z.E., Mariani, V.C. and Darche, S. (2012) Mass Transfer during the Osmotic Dehydration of West Indian Cherry. LWT_Food Science and Technology, 45, 246-252. http://dx.doi:10.1016/j.lwt.2011.07.032

[18] Azoubel, P.M. and Murr, F.E.X. (2004) Mass Transfer Kinetics of Osmotic Dehydration of Cherry Tomato. Journal of Food Engineering, 61, 291-295. http://dx.doi:10.1016/S0260-8774(03)00132-8

[19] Ferrari, C.C. and Hubinger, M.D. (2008) Evaluation of the Mechanical Properties and Diffusion Coefficients of OsmoDehydrated Melon Cubes. International Journal of Food Science \& Technology, 43, 2065-2074. http://dx.doi:10.1111/j.1365-2621.2008.01824.x

[20] Khin, M.M., Zhou, W. and Pereza, C.O. (2007) Impact of Process Conditions and Coatings on the Dehydration Efficiency and Cellular Structure of Apple Tissue during Osmotic Dehydration. Journal of Food Engineering, 79, 817-827. http://dx.doi:10.1016/j.jfoodeng.2006.02.046

[21] Saputra, D. (2001) Osmotic Dehydration of Pineapple. Drying Technology, 19, 415-425. 
[22] TACO (2006) Tabela Brasileira De Composição De Alimentos/NEPA-UNICAMP. Versão II, NEPA-UNICAMP, Campinas, $113 \mathrm{p}$.

[23] Battholomew, D.P., Paull, R.E. and Rohbach, K.G. (2003) The Pineapple Botany, Production and Uses. Volume 1, CABI Publishing, London, 281-288.

[24] Lo Scalzo, R., Papadimitriu, C., Bertolo, G., Maestrelli, A. and Torreggiani, D. (2001) Influence of Cultivar and Osmotic Dehydration Time on Aroma Profiles of Muskmelon (Cucumis melo, cv. Reticulatus Naud.) Spheres. Journal of Food Engineering, 49, 261-264. http://dx.doi.org/10.1016/S0260-8774(00)00209-0

[25] Silva, W.P., Silva, C.M.D.P.S., Lins, M.A.A. and Gomes, J.P. (2013) Osmotic Dehydration of Pineapple (Ananas comosus) Pieces in Cubical Shape Described by Diffusion Models. LWT_Food Science and Technology, 55, 1-8. http://dx.doi.org/10.1016/j.lwt.2013.08.016

[26] Giangiacomo, R., Torreggiani, D. and Abbo, E. (1987) Osmotic Dehydration of Fruit: Part 1. Sugars Exchange between Fruit and Extracting Syrups. Journal of Food Process Preservation, 11, 183-195.

[27] Corzo, O. and Gomez, E.R. (2004) Optimization of Osmotic Dehydration of Cantaloupe Using Desired Function Methodology. Journal of Food Engineering, 64, 213-219. http://dx.doi.org/10.1016/j.jfoodeng.2003.09.035 